a part of the general programme of encouragement for computing machinery and is intended to help with the automatic processing retrieval of scientific information.

\section{Free Space}

President Johnson announced last week that the United States and the Soviet Union have reached agreement on a treaty banning nuclear weapons from space. The treaty, drawn up by the United Nations Outer Space Committee, has yet to be ratified by the General Assembly, but the agreement of the two major powers would seem to make this a formality.

Signatories to the treaty agree to abide by international law, and not to claim sovereignty over any part of outer space, including the Moon. Military bases, weapon testing and military manoeuvres in space are all forbidden, but military personnel may be used for scientific research or other peaceful purposes. Astronauts are to be thought of as envoys of mankind, and helped in the event of accident or emergency landing. Ownership of things launched into space remains with the country of origin, so that it can claim them back if they land in someone else's back yard, and is liable for any damage they cause.

The treaty also pursues the idea of international co-operation in space. Experiments likely to be dangerous or harmful must be avoided, or only carried out after consultation, and all signatories are to have equal opportunities of observing the flight of objects launched by other signatories. As in Antarctica, all bases or space vehicles are to be open to inspection, subject to reasonable advance notice. The treaty becomes effective as soon as it is signed, and states opting out must give one year's notice.

\section{Quality and Quantity}

THE exponential growth of pure science will be halted, Professor Michael Swann believes, not by the blunt instrument of Treasury intervention but by a shortage of manpower. The growth so far has been achieved at the expense of other things and has left the schools and industry short of scientists. The deployment of scientists in Britain leaves much to be desired. In the past two years, more British scientists with doctorates have joined American than British companies. What can be done? "Sir Willis Jackson doesn't know, I don't know, nobody knows." Negative policies, like making life less pleasant at universities, are not to be considered. Professor Swann was delivering a discourse at the Royal Institution on December 9.

Britain may be lucky in one respect, he thought. In setting up the four research councils, the country had stumbled on a system which might be able to solve at least some problems. The Medical and Agricultural Research Councils both have very similar budgets, but spend them in different ways-the Medical Research Council in universities and the Agricultural Research Council in large laboratories. The two biological subjects are a complete contrast. Professor Swann declined to say which system was best; both, he said, were successful, and in any case the important point was the flexibility which they were allowed. The councils were free to spend money as they wished, and in fifty years their roles might be completely reversed. A system which allowed this to happen was admirable.
Universities in this country often felt hard up, Professor Swann said, both by comparison with government laboratories and by comparison with universities in the United States. He suggested that this was partly their own fault; professors tended to spend all the money they get from the University Grants Committee on academic staff, and to forget about technical staff in the hope that the research councils would bail them out. If professors would make do with 20 per cent fewer staff, they would have 50 per cent more spending money. As for the comparison with the United States, it was an illusion. The average amount spent by each government per university research worker was not very different. It seems different only because the universities in the United States which people visit are the good universities, and because the Americans are not egalitarian. They believe, in fact, in centres of excellence, while the British believe in supporting all universities equally. Professor Swann said that too many British universities have too few students, and in trying to cover all subjects end up with very small departments. An academic staff of 15-20 in each department was the critical figure, which implies a university of at least 3,000 students. But the new British universities are only half this size. So far the only centres of excellence which have been consciously developed are those concerned with "big" science-high energy physics, for examplebut perhaps the research councils would be able to do the same for "little" science by giving grants to departments which are particularly good at something.

But are there, in fact, centres of excellence in Britain? Professor Swann looked to Oxford and Cambridge as the obvious candidates. Although the University Grants Committee treated them in exactly the same way as other universities, their endowments gave them an edge. How much of an edge was difficult to assess, because of the evasions in the Franks Report. Although Franks treated Oxford as an average university, this was unfair; it ought to be a cheap university because it was arts-centred. Professor Swann estimated that Oxford was 50 per cent more expensive than other universities. Did this make it better? "Not, perhaps, strikingly much."

Professor Swann started so many hares that even his critics would have found it hard to follow all of them. In his lecture he asked more questions than he answered, but they seemed to be the right questions.

\section{Quarts in Pint Pots}

THERE were reports last week that the University of Manchester Institute of Science and Technology is trying to fit four terms into the academic year. In fact the idea is no more than a twinkle in the eye of Professor Colin Adamson, the chairman of the Department of Engineering and Electronics. In a document to the University Grants Committee, Professor Adamson points out that if his department is to double the present number of postgraduates from 130 to 260 , the number of staff members will also have to be doubled. The present plan is to increase the intake of undergraduates from 90 to 120 per year, but these would only fill the teaching laboratories for half the year. The increased staff could in fact cope with 240 undergraduates each year without extra work if the undergraduates were admitted in two batches of 120 . 